\title{
MENGISI KESENJANGAN ANTARA JUMLAH HASIL PENELITIAN MAHASISWA DALAM BIDANG BIOLOGI DAN KETERSEDIAAN MEDIA PUBLIKASINYA
}

\author{
RoMANUS EDY PRABOWO \\ Editor-in-chief SCRIPTA BIOLOGICA \\ Fakultas Biologi, Universitas Jenderal Soedirman, Jalan dr. Suparno 63 Purwokerto 53122
}

Publikasi ilmiah dalam dunia akademik adalah sebuah keharusan bagi seorang peneliti untuk melaporkan hasil studi teoritis maupun empiris berdasarkan penelitian. Artikel yang diterbitkan dalam berkala ilmiah dapat digunakan untuk rujukan penelitian, bahan pengajaran di pendidikan tinggi, maupun sebagai acuan aplikasi praktis dalam bidang terkait. Bagi peneliti termasuk mahasiswa peneliti, artikel ilmiah sangat berguna untuk menjaga kekinian pengetahuan dan metode penelitian dengan mengacu pada temuan dan perkembangan baru bidang ilmu yang ditekuni peneliti, yang kemudian digunakan untuk mengarahkan rencana penelitian selanjutnya.

Publikasi ilmiah hasil penelitian (original scientific research paper) yang dikenal sebagai literatur primer, mempunyai bagian yang paling esensial dari suatu artikel ilmiah yaitu sitasi. Suatu artikel ilmiah dinilai dari seberapa banyak sitasi dirujuk oleh artikel ilmiah lain yang lebih baru. Jumlah sitasi yang diperoleh menunjukan faktor dampak atau besarnya pengaruh dari suatu artikel ilmiah terhadap penelitian lain yang lebih baru yang umum dikenal sebagai impact-factor. Oleh karena itu suatu hasil penelitian akan mempunyai pengaruh atau dampak bila hasil penelitian tersebut dipublikasikan. Namun demikian pengaruh atau dampak suatu artikel ilmiah yang dipublikasikan tersebut juga ditentukan oleh reputasi berkala ilmiahnya, sehingga kita mengenal ada berkala bereputasi internasional, nasional, dan lokal. Ada banyak hal yang membentuk reputasi suatu berkala ilmiah, namun saat ini bukan hal tersebut yang akan menjadi perhatian, tetapi bagaimana mendorong begitu banyak hasil penelitian terutama hasil penelitian mahasiswa untuk bisa didiseminasikan sebagai artikel dalam berkala ilmiah.

Proses pembentukan insan peneliti dengan kontribusi publikasi kepada masyarakat ilmiah secara umum dimulai di pendidikan tinggi, dari program sarjana, program magister, hingga program doktoral. Mahasiswa pada setiap tingkatan pendidikan tersebut mempunyai persyaratan atau tuntutan yang berbeda dalam hal diseminasi hasil penelitiannya. Pada perkembangannya proses ini didoromg lebih keras dengan adanya surat edaran Direktorat Jenderal Pendidikan Tinggi, Kementerian Pendidikan dan Kebudayaan nomor 152/E/T/2012 terkait kewajiban publikasi karya ilmiah, yang menyebutkan bahwa: 1) untuk lulus program Sarjana harus menghasilkan makalah yang terbit pada jurnal ilmiah, 2) untuk lulus program Magister harus telah menghasilkan makalah yang terbit pada jurnal ilmiah nasional, dan 3) untuk lulus program Doktor harus telah menghasilkan makalah yang diterima untuk terbit pada jurnal internasional. Terkait kewajiban tersebut terdapat kesenjangan yang sangat besar antara jumlah hasil penelitian mahasiswa dalam bidang biologi dan ketersediaan media publikasinya. Di Indonesia saat ini terdapat tidak kurang dari 240 program studi S1, 31 program studi S2, dan 10 program studi S3 bidang biologi yang terakreditasi. Sedangkan jumlah berkala ilmiah terkait bidang biologi masih sangat kurang, sementara hasil penelitian mahasiswa terutama program studi S1 dinilai kurang kompetitif untuk masuk dalam berkala ilmiah yang tersedia. Meskipun tidak dipungkiri bahwa kualitas hasil penelitian mahasiswa program studi S1 secara umum tidak semua dapat dinilai "layak" untuk dipublikasikan, namun upaya untuk mendorong proses diseminasi hasil penelitian mahasiswa dalam berkala ilmiah tetap perlu dilakukan.

Berkala ilmiah SCRIPTA BIOLOGICA ini dibuat untuk mengisi celah besar kesenjangan tersebut. Tersedia secara online dalam 4 nomer terbitan per volume per tahun, kualitas artikel ilmiahnya tetap dipertahankan dengan kombinasi editorial-review dan peer-review. SCRIPTA BIOLOGICA menerapkan lisensi Creative Commons Attribution BY-SA, di bawah lisensi ini hak cipta atas artikel riset yang dipublikasikan tetap ada pada penulis. Penulis memberikan lisensi kepada SCRIPTA BIOLOGICA untuk mempublikasikan artikel risetnya dan menyatakan SCRIPTA BIOLOGICA sebagai penerbit pertama. Di bawah lisensi ini penulis juga memberikan hak kepada pihak ketiga untuk menggunakannya secara bebas; mengunduh, mencetak, menggunakan, mengubah, menyebarkan, dan atau menyalin sebagian atau seluruh bagian artikel ilmiah dalam berkala ini, selama identitas penulis, detil sitasi, dan jurnal penerbit tetap disertakan dan dinyatakan secara jelas.

Semoga berkala ilmiah online SCRIPTA BIOLOGICA bisa memberikan kontribusi dalam usaha bersama insan akademik untuk meningkatkan akses pada hasilhasil penelitian, utamanya penelitian mahasiswa dalam bidang biologi, sehingga pengetahuan serta manfaatnya dapat digunakan oleh masyarakat secara lebih luas. Publikasi perdana SCRIPTA BIOLOGICA volume 1 nomer 1 ini adalah langkah awal untuk secara berkelanjutan membuat lebih banyak hasil penelitian mahasiswa dalam bidang biologi menjadi terdiseminasi, terdokumentasi, dan tersertifikasi. 